\title{
Multidirectional traps as a new assessment system of soil wind erosion
}

\author{
Rocío Guerrero ${ }^{\oplus}$, Juan Luis Valenzuela ${ }^{2}$, Sonia Chamizo ${ }^{1} \odot$, José Luis Torres-Moreno ${ }^{3 \odot}$, Carlos Asensio $^{1 *} \odot$
}

${ }^{1}$ Universidad de Almería - Depto. de Agronomia, Campus de La Cañada, Ctra Sacramento, s/n - 04120 - Almería España.

¿Universidad de Almería - Depto. de Biología y Geología, Campus de La Cañada, Ctra Sacramento, s/n - 04120 Almería - España.

3Universidad de Almería - Depto. de Ingeniería, Campus de La Cañada, Ctra Sacramento, s/n - 04120 - Almería España.

*Corresponding author <casensio@ual.es>

Edited by: Silvia del Carmen Imhoff

Received October 28, 2020

Accepted May 11, 2021
ABSTRACT: We tested a new type of wind-transported particle collector (multidirectional traps, MDt) in southeast Spain to forecast particle movement in three different soil types. The MDt collectors are easy to manufacture from thermoplastic filaments with an industrial 3D printer. The collectors tested were very efficient. Our research was carried out on unplowed Calcisols and on orange and olive-cropped Fluvisols and Luvisols, respectively. The results from the logs of nine vaned masts, each with four MDt collectors at different heights, on Calcisols, Fluvisols and Luvisols were compared with the wind erodible fraction of these soils (EF) empirically estimated and with their erosion rates calculated in a wind tunnel of our own design with a built-in laser scanner. These new collectors can differentiate the collected sediments by their direction of origin and arranged in a network of masts, enabling to distinguish overall particle loss or deposition, which is not detectable with the wind tunnel due to the work scale and no windward deposits, as it is a closed device. Comparison of the calculated EF and the total mass of transported particles recorded by the MDt collectors showed very good correlation $\left(\mathrm{R}^{2}=\right.$ 0.9144) with an even better relationship between the results of the wind tunnel and collectors $\left(R^{2}=0.9741\right)$. Required precision, financing, and execution time are important in determining the use of the device. We conclude that this device shows good potential.

Keywords: semi-arid environment, wind tunnel, dust collectors, soil crusts

\section{Introduction}

Wind erosion is a major cause of land degradation worldwide. Therefore, more studies are needed to aid in policy and decision-making (Panagos et al., 2012). The decrease in soil compaction, in its vegetation cover, and in its OM content increases the risk of wind erosion of the soil (Novara et al., 2011; Prosdocimi et al., 2016; Arjmand Sajjadi and Mahmoodabadi, 2015). Climate also influences erosion, making some regions more affected by these processes (Borrelli et al., 2016; Weber et al., 2017). Obviously, human activity in cultivated areas has a very important role.

Analyzing Mediterranean cultivation systems, Benlhabib et al. (2014) recommended sustainable cultivation technologies, which showed a significantly positive effect on productivity and yield. Colazo and Buschiazzo (2010, 2015) and Zobeck et al. (2013) confirmed that the crop increased the wind-erodible fraction $(\mathrm{EF})$ of the soil and reduced the stability of dry aggregates in medium-texture soils, which weakened soil structure in addition to causing OM loss and breakdown of aggregates. Fryrear et al. (1994) proposed the use of a multiple regression equation for calculating $\mathrm{EF}$, when a rotary sieve is not available.

There are many models of wind tunnels for field simulations. Some specific components, being a laser scanner the most important, have been added to our prototype (Giménez et al., 2019). The built-in laser scanner shows changes in the micro-relief and allows quick estimates of the volume of eroded soil. Many samplers have also been developed to determine the amount of material carried by the wind (Goossens et al., 2000). According to Zobeck et al. (2003), the choice of collector type depends on the study to be carried out, precision required, and financial resources. $\mathrm{M}$ o d e $1 \mathrm{~s}$ available vary in size, shape, type of material to be quantified, and collection efficiency. Feras et al. (2008) demonstrated that the efficiency of the sediment trap depends mainly on particle size and wind speed. Mendez et al. (2011) and Goossens and Buck (2012) found that efficiency increased as particle size decreased and wind speed increased. The placing of traps at different heights allows measuring vertical sediment flow (Basaran et al. 2011). We used new wind-borne particle collectors, called multidirectional traps (MDt), over non-plowed Calcisols with little coverage (around $5 \%$ ) and over orange and olive-cropped Fluvisols and Luvisols with coverages around 30 and $20 \%$, respectively. The collectors were built from thermoplastic filaments, adequate to resist the impacts of wind-borne particles.

Our objectives here were to study the amount of material lost by the wind action under the same conditions and by different methods, in different representative soil types in southeast Spain, as well as to compare the differences between the eroded material reported by traditional methods and a new technique, evaluating the results.

\section{Materials and Methods}

The study site is located in the province of Almería, southeast Spain (Figure 1). The climate is semi-arid Mediterranean with an average annual temperature of $18.7^{\circ} \mathrm{C}$ and rainfall of $256 \mathrm{~mm}$. The dominant geological material belongs to a Miocene sedimentary series. Natural plant communities are isolated native shrubs, but today intense horticultural and tree crops are also 
grown. According to the IUSS WRB Working Group (2015), the soils studied are haplic Calcisol (CL), aricgypsiric Fluvisol (FL) and hapli-chromic Luvisol (LV).

Table 1 shows the site, sampling date, average wind speed and direction, average temperature and relative humidity of the soils studied. In all cases, there were wind gusts over $15 \mathrm{~m} \mathrm{~s}^{-1}$.

Meteorological records were taken from the automatic meteorological station network of the Andalusian Agricultural and Fisheries Research and Education Institute (IFAPA) (http://www. juntadeandalucia.es/agriculturaypesca/ifapa/ria/servlet/ FrontController" http://www.juntadeandalucia.es/ agriculturaypesca/ifapa/ria/servlet/FrontController), an institution of the Junta de Andalucía (Andalusian regional government).

Four replicate samples from the top $5 \mathrm{~cm}$ of soils were taken and analyzed. Texture data were found by the Robinson pipet method. Organic carbon content was analyzed using the Walkley-Black wet digestion method. Gas volumetry was used to determine the carbonate content. To determine the bulk density, $100-\mathrm{cm}^{3}$ cylinders were used for the dry weight of the sample to be referred to by cylinder volume.

The wind-erodible fraction of the soils was calculated following Eq. (1) of Fryrear et al. (1994):

$\mathrm{EF}=29.09+0.31$ sand +0.17 silt +0.33 sand $/$ clay -2.59 organic matter $-0.95 \mathrm{CaCO}_{3}$

where: all variables, including wind-erodible fraction (EF) of the soils, are expressed in \%.

Wind erosion was monitored in a wind tunnel to study the effects of a wind stream at constant speed on the soil surface (Figure 2A). The wind tunnel has a telescopic structure. The middle section is equipped with a NextEngine Desktop 3D laser scanner to find changes in the micro-relief first and later in the volume of eroded soil

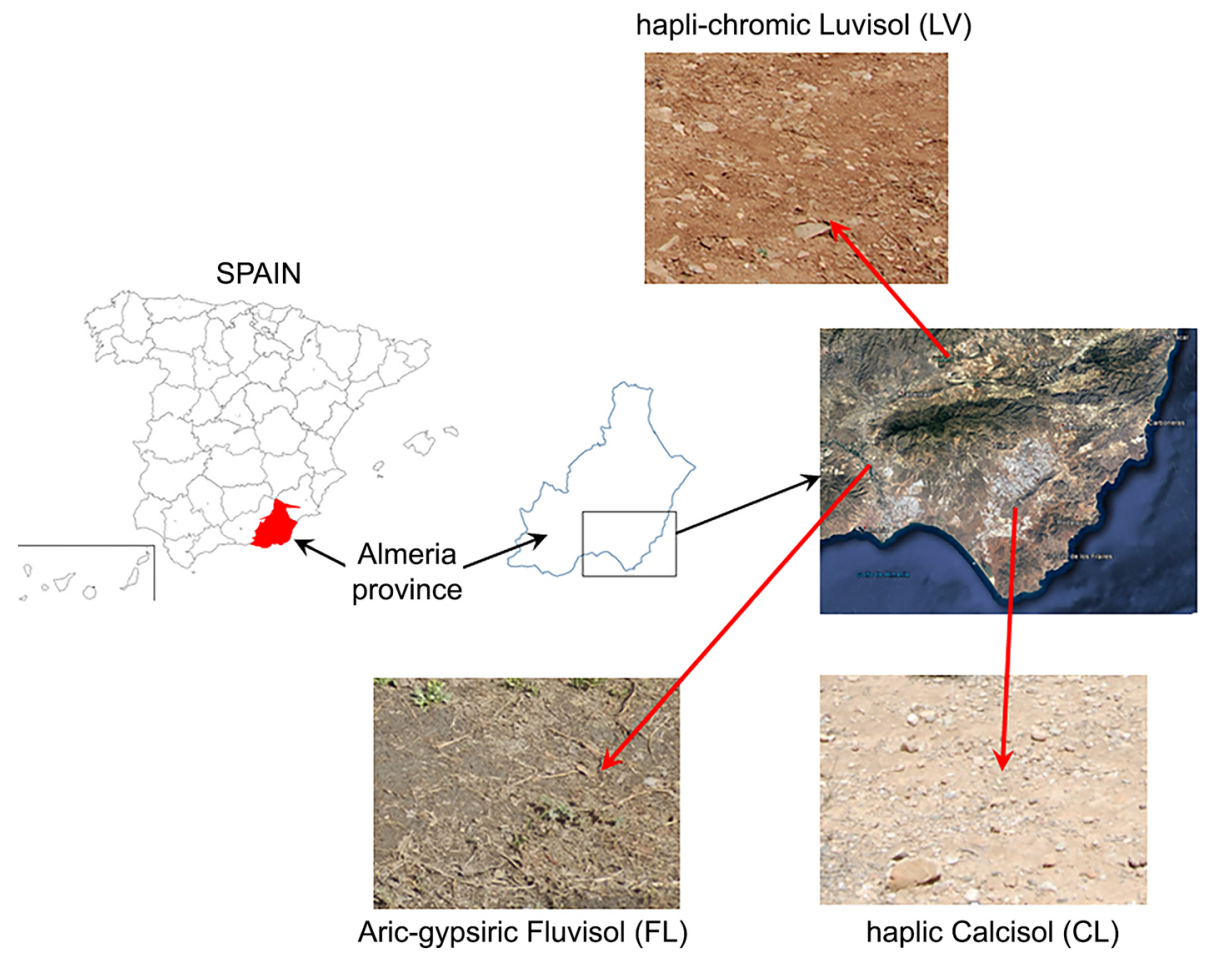

Figure 1 - Location of soils studied.

Table 1 - Coordinates, altitude, sampling date, and climatic characteristics of the soils studied.

\begin{tabular}{|c|c|c|c|c|c|c|c|c|}
\hline \multirow{2}{*}{ SOIL } & \multicolumn{3}{|c|}{ Location } & \multirow{2}{*}{ Date } & \multirow{2}{*}{$\begin{array}{l}\text { Averaged } \\
\text { wind speed }\end{array}$} & \multirow{2}{*}{$\begin{array}{c}\text { Averaged } \\
\text { direction }\end{array}$} & \multirow{2}{*}{$\begin{array}{l}\text { Averaged } \\
\text { temperature }\end{array}$} & \multirow{2}{*}{$\begin{array}{l}\text { Averaged } \\
\text { relative humidity }\end{array}$} \\
\hline & & dinates & Altitude & & & & & \\
\hline & & & (m) a.s.l. & & $\mathrm{m} \mathrm{s}^{-1}$ & $\circ$ & ${ }^{\circ} \mathrm{C}$ & $\%$ \\
\hline $\mathrm{CL}$ & $36^{\circ} 51^{\prime} 41.72^{\prime \prime} \mathrm{N}$ & $2^{\circ} 16^{\prime} 26.04^{\prime \prime} \mathrm{W}$ & 91 & $31 / 05 / 2019$ & 3.0 & 86.1 & 21.6 & 43 \\
\hline $\mathrm{FL}$ & $36^{\circ} 57^{\prime} 58.23^{\prime \prime} \mathrm{N}$ & $2^{\circ} 28^{\prime} 9.58^{\prime \prime} \mathrm{W}$ & 164 & $27 / 03 / 2019$ & 2.6 & 73.4 & 10.1 & 57 \\
\hline LV & $37^{\circ} 06^{\prime} 53.85^{\prime \prime} \mathrm{N}$ & $2^{\circ} 18^{\prime} 5.63^{\prime \prime} \mathrm{W}$ & 573 & $23 / 01 / 2019$ & 4.8 & 239.3 & 11.1 & 52 \\
\hline
\end{tabular}

$\mathrm{CL}=$ Calcisols; $\mathrm{FL}=$ Fluvisols; $\mathrm{LV}=$ Luvisols. 
(Asensio et al., 2016). Following the criteria of Fister and Ries (2009), the wind tunnel experiments lasted $10 \mathrm{~min}$ at a wind speed of $7.6 \mathrm{~m} \mathrm{~s}^{-1}$ monitored at a height of $70 \mathrm{~cm}$. This wind speed is the maximum daily average recorded over the last 20 years by the agroclimatic stations in our region. The soil surface was scanned before and after wind simulation, in each case, by using high definition and macro mode. These scans provided two point clouds for each scatterplot, from which two digital terrain models (DTM) were automatically generated with a resolution of $0.1 \times 0.1 \mathrm{~cm}$. The eroded volume of the soil was estimated as the difference between the DTMs. Therefore, knowing the bulk density of each soil, the amount of soil lost could be estimated (Asensio et al., 2016). In this device, the air stream speed is a reliably reproducible fixed parameter. Four different plots were chosen on each soil type to reflect the natural variability of the test plots for the collected data.

In addition to the wind tunnel, we used our own patented collectors (Asensio et al., 2015a) manufactured by an industrial 3D printer from a glycol-modified ethylene polyterephthalate (PETg) thermoplastic filament. PETg is a tough material, ideal for objects subjected to mechanical stress, hard, flexible and resistant. Figure 2B shows a diagram of the design of this new collector, which we call a multidirectional trap (MDt). The air with the material enters them through a rectangular $2 \times 5 \mathrm{~cm}$ opening and a grill inside modifies its movement. The material is deposited in a removable structure, with a fixed, ringshaped base. There are eight north-facing compartments in the ring, which can differentiate the captured materials by the direction of origin. Each of these collectors is attached to a vaned mast (Figure 2C). According to Asensio et al. (2015b), the MDt collector efficacy (74 \%) is higher for fine grain sizes. Each experiment with the collectors lasted for 24 consecutive hours.
A network of nine vaned masts was mounted with the MDt traps placed at 0.35, 0.70, 1.05 and $1.40 \mathrm{~m}$ heights to ensure that their inlets always faced the main wind direction. The rotating masts were spaced $50 \mathrm{~m}$ apart to avoid interference from the others. This was performed in each soil type. Figure 3 shows the masts distribution on an olive-cropped Luvisol.

As our collectors were placed at different heights on the mast starting at $0.35 \mathrm{~m}$, the difference in the rate of soil lost with distance from the soil surface had to be measured empirically using a mathematical model that predicts the amount of sediment on the soil surface. Sediment flux $\left(\mathrm{qz}_{,} \mathrm{kg} \mathrm{m}^{-2}\right)$ at each trap height $(\mathrm{z}, \mathrm{m})$ was found by Eq. (2).

$q_{z}=\frac{m}{A}$

where: $m$ - sediment weight $(\mathrm{kg})$ captured by each collector at a given height; $A$ - inlet area $\left(\mathrm{m}^{2}\right)$ of a collector.

Then, sediment flux was predicted $\left(q_{z \cdot \exp ^{\prime}} \mathrm{kg} \mathrm{m}^{-2}\right)$ by an exponential equation for every amount modelled in Eq. (3):

$q_{z \cdot \exp }=q_{0} \cdot e^{-\alpha z}$

where: $q_{0}$ - amount of sediment modelled at $z=0$ $\left(\mathrm{kg} \mathrm{m} \mathrm{m}^{-2}\right) ; \alpha$ - slope factor of exponential regression equation $(\mathrm{m})$.

The sediment transport rate $\left(\mathrm{Qr}, \mathrm{kg} \mathrm{m}^{-1}\right)$ was then determined by integrating $q_{z \text { exp }}\left(\mathrm{kg} \mathrm{m}^{-1}\right)$ predicted using Eq. (4):

$Q_{r}=\int_{0}^{h} q_{z \cdot \exp } d z$
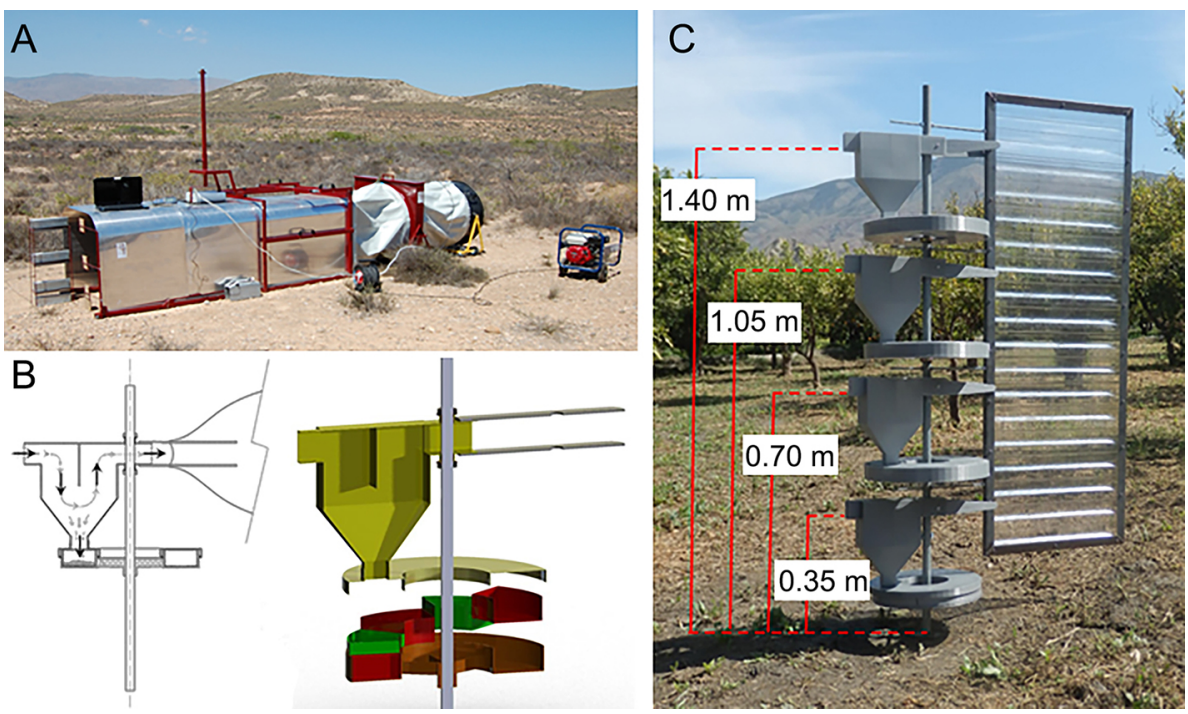

Figure 2 - A) Wind tunnel on a Calcisol; B) Schemes of MDt collectors; C) Mast and wind vane with MDt collectors on a Fluvisol. 
where: $h$ - maximum particle transportation height $(\mathrm{m})$ recorded.

Total mass transport $\left(Q_{t}, \mathrm{~kg}\right)$ was calculated by Eq. (5):

$Q_{t}=\left(\frac{Q_{r}}{\eta}\right) L$

where: $\eta$ - trap efficiency; $L$ - plot width.

The amount of material lost (or deposited) was calculated as the difference in the sediment flux or sediment transport rate between sampling points located windward and leeward in the prevailing wind direction. Thus, positive differences indicated gains, while negative differences referred to material loss.

A non-parametric Wilcoxon signed-rank test was performed to determine whether the amount of material captured at the same heights by the collectors differed. We compared the total amount collected and the amount collected by the windward oriented compartment, for each soil type.

\section{Results}

Soil characteristics recorded for Calcisols, Fluvisols, and Luvisols in the study site are shown in Table 2.

The soil surfaces are not highly stony, except on $\mathrm{CL}$, and the average gravel content for the different soil types is $22 \%$ in $\mathrm{CL}, 19 \%$ in $\mathrm{FL}$, and $43 \%$ in LV.

The wind tunnel allowed to focus on losses and deposits only within a microplot that the laser scanner

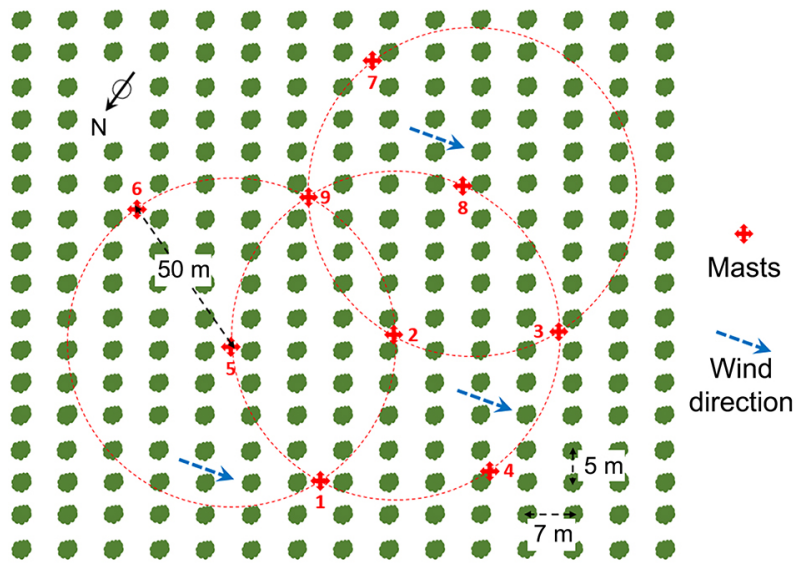

Figure 3 - Example of masts distribution on a Fluvisol. can detect. Table 3 shows the results for the three soil types blown into the wind tunnel at the same artificially generated wind speed $\left(7.2 \mathrm{~m} \mathrm{~s}^{-1}\right)$. It also includes the average wind-erodible fraction of the soils, following Fryrear et al. (1994).

As described above, the MDt collectors (Figures $2 \mathrm{~B}$ and $2 \mathrm{C}$ ) allowed to differentiate the direction the particles trapped coming from with their internal compartments (inside the ring structure). Figure 4 shows sediment fluxes on the MDt collector estimated for each soil type. We determined sediment flux data from the windward compartments recorded and the total amount corresponding to the whole collector (sum of all compartments). Sediment transport rates were found by integration of the exponential Eq. (3).

As the main wind direction for each soil type was different (Figure 5), we compiled a dataset of the differences between the sampling points located upwind

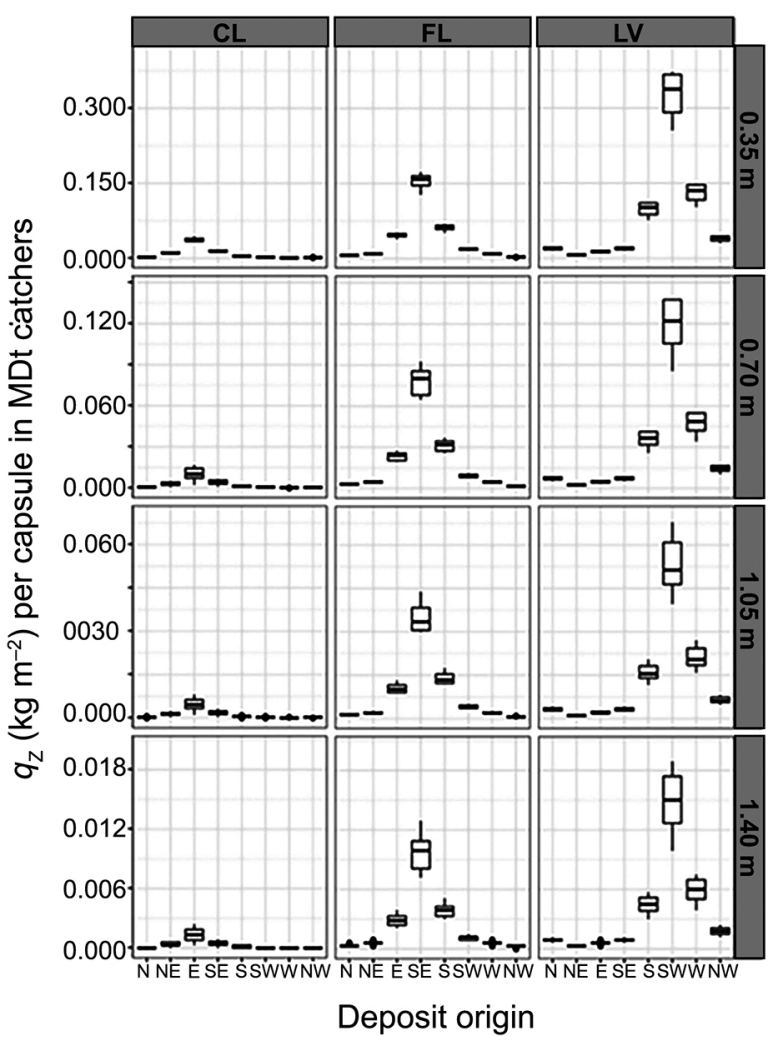

Figure 4 - Average sediment fluxes by soil type, collector height, and directional compartment.

Table 2 - Soils characteristics.

\begin{tabular}{|c|c|c|c|c|c|c|c|c|c|c|}
\hline SOIL & VC Sand & Coarse Sand & Medium Sand & Fine Sand & VF Sand & Coarse Silt & Fine Silt & Clay & $\mathrm{OM}$ & $\mathrm{CO}_{3}=$ \\
\hline & & & & & $-\mathrm{g} \mathrm{kg}^{-1}$ & & & & & $\%$ \\
\hline $\mathrm{CL}$ & $60 \pm 5$ & $61 \pm 4$ & $95 \pm 7$ & $193 \pm 16$ & $225 \pm 18$ & $75 \pm 8$ & $117 \pm 11$ & $174 \pm 14$ & $15.5 \pm 1.9$ & $40 \pm 3$ \\
\hline $\mathrm{FL}$ & $21 \pm 4$ & $52 \pm 5$ & $70 \pm 6$ & $87 \pm 9$ & $155 \pm 12$ & $220 \pm 19$ & $183 \pm 17$ & $212 \pm 23$ & \multirow{2}{*}{$\begin{array}{l}36.5 \pm 5.7 \\
49.0 \pm 5.0\end{array}$} & $24 \pm 2$ \\
\hline LV & $0 \pm 1$ & $55 \pm 4$ & $62 \pm 3$ & $89 \pm 8$ & $259 \pm 22$ & $267 \pm 21$ & $63 \pm 6$ & $204 \pm 26$ & & $2 \pm 1$ \\
\hline
\end{tabular}

$\mathrm{VC}=$ Very coarse; $\mathrm{VF}=$ Very fine; $\mathrm{OM}=$ Organic matter; $\mathrm{CL}=$ Calcisols; $\mathrm{FL}=$ Fluvisols; $\mathrm{LV}=$ Luvisols. 
and leeward in the prevailing wind direction (Table 4). Thus, positive differences indicated gains and negative differences showed a loss of material.

Table 5 shows the sediment transport rate balance, where the MDt collectors clearly indicate deposition in Calcisols compared to loss in the other soils tested.

Finally, Table 6 shows the results for total mass transport.

\section{Discussion}

Calcisols appeared in unplowed areas with little protection from the direct wind impact. Trees (orange and olive orchards, respectively) protected both Fluvisols and Luvisols and both soils were crusted, but crusting was more significant in the Luvisols. Immediately after tillage, Luvisols are highly erodible by wind, but according to Asensio et al. (2016), their physical crust tends to recover within 10-12 days. In the wind tunnel study, the average soil loss was over 14 folds higher in recently tilled Luvisols than in crusted soils.

Table 3 - Wind erosion in the wind tunnel, after four replicates (A to D).

\begin{tabular}{lrrrrrrrrr}
\hline SOIL & \multicolumn{4}{c}{$\begin{array}{c}\text { Lost (Laser scanner) } \\
\text { (mm) }\end{array}$} & $\begin{array}{c}\text { Bulk } \\
\text { density }\end{array}$ & $\begin{array}{c}\text { Wind erosion } \\
\text { (Tunnel) }\end{array}$ & \\
\cline { 2 - 8 } & A & B & C & D & Average & & & \\
\hline & & & & & & $\mathrm{t} \mathrm{m}^{-3}$ & tha $^{-1}$ & $\%$ \\
CL & 0.11 & 0.17 & 0.10 & 0.15 & 0.13 & 1.41 & 1.83 & 11 \\
FL & 0.69 & 0.84 & 0.71 & 0.95 & 0.8 & 1.29 & 10.32 & 16 \\
LV & 1.02 & 1.45 & 1.14 & 1.50 & 1.28 & 1.22 & 15.62 & 35 \\
\hline
\end{tabular}

$\mathrm{EF}=$ Wind erodible fraction; $\mathrm{CL}=$ Calcisols; $\mathrm{FL}=$ Fluvisols; $\mathrm{LV}=$ Luvisols.
According to the collector data, the freshly plowed Luvisols produced the highest emission flux, in agreement with other experimental studies (Marzen et al., 2019). Tillage led to a partial breakdown of crust and clods, generating a comparably high proportion of incoherent substrate of the fine fractions most easily erodible by wind. As the OM was not very high, mechanical reduction of aggregate sizes by tilling decreased the aggregate stability and further increased the amount of winderodible sediment on the soil surface, mainly under dry soil conditions (Colazo and Buschiazzo, 2010, 2015). The long drought aggravated the situation. Wind erosion leads to the sorting of soil material and gradually removes predominantly the finest grain sizes, silt and clay, including a high proportion of soil nutrients (Katra et al., 2016); therefore, wind erosion is a severe threat to soil management, for both 5-year old orange (FL) and 8-year-old olive (LV) orchards.

Figure 6 shows the boxplots of differences between material trapped on windward compartments and total amount of material trapped by the MDt collectors for each soil type. If one set of collectors systematically captures more than the other sets, the entire boxplot is above or below 0 . The results of the statistical test applied indicate that, in most cases, the differences found are not statistically significant $(p$-value $>0.05)$. For Calcisols, the test detected significant differences $(p$-value $<0.05)$ mainly in windward collectors. Future experiments need to analyze the influence in high carbonate content and its aggregating role in this soil type, in addition to the consequences of its very stony surface.

Table 4 - Mast numbers where values differed on each soil type.

\begin{tabular}{|c|c|c|c|c|c|c|c|}
\hline SOIL & Main wind direction & & Diffe & es in sedime & ux catched & lasts & \\
\hline $\mathrm{CL}, \mathrm{FL}$ & from East & M $6-$ M 5 & M 9-M 2 & M 7-M 8 & M 5-M 1 & M $2-\mathrm{M} 4$ & M $8-$ M 3 \\
\hline LV & from Southwest & M $4-M 1$ & M 3-M 2 & M $2-$ M 5 & M $8-M 9$ & M $9-$ M 6 & \\
\hline
\end{tabular}

$\mathrm{CL}=$ Calcisols; $\mathrm{FL}=$ Fluvisols; $\mathrm{LV}=$ Luvisols.

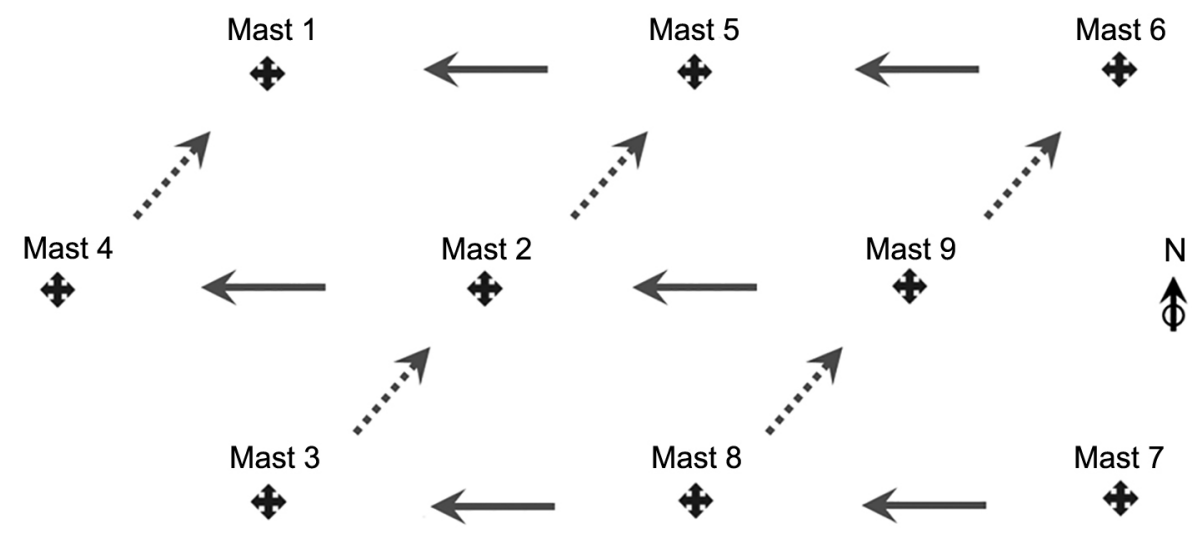

Figure 5 - Mast locations with different arrows showing main wind directions. 
Evaluation of Calcisol sediment transport rates and their balance indicated that material was being deposited not lost in this soil. Data from wind tunnel evaluation showed low Calcisol loss. The device is a closed structure and cannot detect windward deposition. However, the wind tunnel rapidly provided replicable accurate data, mainly on soil wind erodibility.

Finally, a comparison of total mass transport of each soil type from collectors and the calculated wind erodible fraction showed very good linear correlation $\left(\mathrm{R}^{2}=0.9144\right)$, which was better than the wind erosion reported by the wind tunnel $\left(\mathrm{R}^{2}=0.9741\right)$.

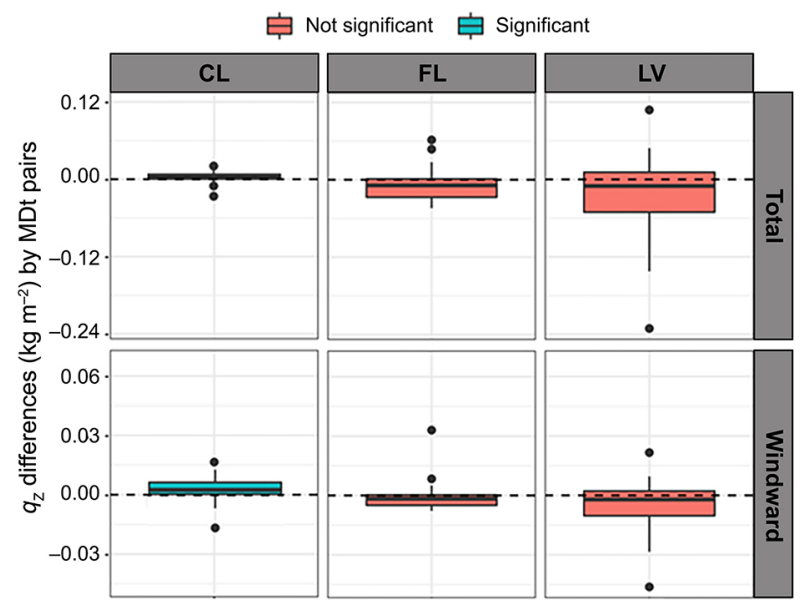

Figure 6 - Comparison of sediment flux at each trap height (qz) differences between MDt collectors (total and windward origin) and soil types.

Table $\mathbf{5}$ - Sediment transport rate balance.

\begin{tabular}{lcc}
\hline SOIL & \multicolumn{2}{c}{$Q_{r}$ balance } \\
\cline { 2 - 3 } & MDt windward & MDt total \\
\hline $\mathrm{CL}$ & 0.0006 & 0.0014 \\
$\mathrm{FL}$ & -0.0497 & -0.0782 \\
$\mathrm{LV}$ & -0.0260 & -0.0465 \\
\hline
\end{tabular}

$\mathrm{CL}=$ Calcisols; $\mathrm{FL}=$ Fluvisols; $\mathrm{LV}=$ Luvisols.

Table 6 - Total mass transport $\left(Q_{t}\right)$.

\begin{tabular}{|c|c|c|c|c|c|c|c|c|c|c|}
\hline \multirow[t]{2}{*}{ SOIL } & \multicolumn{9}{|c|}{$\begin{array}{l}\mathrm{Q}_{\mathrm{t}}(\mathrm{MDt} \text { windward) } \\
(\mathrm{kg})\end{array}$} & \multirow[b]{2}{*}{ Average } \\
\hline & 1 & 2 & 3 & 4 & 5 & 6 & 7 & 8 & 9 & \\
\hline $\mathrm{CL}$ & 2.1892 & 2.3268 & 2.7776 & 1.9556 & 3.1625 & 2.4923 & 1.9254 & 2.9917 & 2.7608 & 2.5091 \\
\hline $\mathrm{FL}$ & 11.3326 & 10.7330 & 9.7798 & 12.8988 & 12.0633 & 12.5803 & 9.7422 & 10.8261 & 12.5178 & 11.386 \\
\hline LV & 23.5806 & 19.0067 & 19.8709 & 27.7675 & 26.9378 & 28.0535 & 17.3698 & 22.1445 & 22.1445 & 22.9862 \\
\hline \multirow[t]{2}{*}{ SOIL } & \multicolumn{9}{|c|}{$\begin{array}{c}\mathrm{Q}_{\mathrm{t}}(\mathrm{MDt} \text { total) } \\
(\mathrm{kg})\end{array}$} & \\
\hline & 1 & 2 & 3 & 4 & 5 & 6 & 7 & 8 & 9 & Average \\
\hline$\overline{C L}$ & 4.1592 & 4.2747 & 4.7432 & 3.4210 & 5.3093 & 4.3949 & 3.6414 & 5.0959 & 4.8721 & 4.4346 \\
\hline $\mathrm{FL}$ & 21.5343 & 20.7062 & 18.5467 & 24.7000 & 23.2189 & 24.2446 & 19.9898 & 20.7871 & 23.9254 & 21.9614 \\
\hline LV & 41.1931 & 33.2460 & 34.8096 & 48.5924 & 47.4469 & 49.2885 & 32.2756 & 38.8311 & 46.3171 & 41.3334 \\
\hline
\end{tabular}

$\mathrm{CL}=$ Calcisols; $\mathrm{FL}=$ Fluvisols; $\mathrm{LV}=$ Luvisols. 
Asensio, C.; López, J.; Lozano, F.J. 2015a. Multidirectional collector of particles carried by the wind $=$ Colector multidireccional de partículas transportadas por el viento. Spanish office of the patents and brand. Ref. ES2470090 B1 (in Spanish).

Asensio, C.; Lozano, F.J.; Ortega, E.; Kikvidze, Z. 2015b. Study on the effectiveness of an agricultural technique based on aeoliandeposition, in a semiarid environment. Environmental Engineering and Management Journal 14: 1143-1150.

Asensio, C.; Lozano, F.J.; Gallardo, P.; Giménez, A. 2016. Soil wind erosion in ecological olive trees in the Tabernas desert (Southeastern Spain): a wind tunnel experiment. Solid Earth 7: 1233-1242. https://doi.org/10.5194/se-7-1233-2016

Basaran, M.; Erpul, G.; Uzun, O.; Gabriels, D. 2011. Comparative efficiency testing for a newly designed cyclone type sediment trap for wind erosion measurements. Geomorphology 130: 343-351. https://doi.org/10.1016/j.geomorph.2011.04.016

Benlhabib, O.; Yazar, A.; Qadir, M.; Lourenço, E.; Jacobsen, S.E. 2014. How can we improve mediterranean cropping systems? Journal of Agronomy and Crop Science 200: 325-332.

Borrelli, P.; Panagos, P.; Ballabio, C.; Lugato, E.; Weynantgs, M.; Montanarella, L. 2016. Towards a Pan-European assessment of land susceptibility to wind erosion. Land Degradation \& Development 27: 1093-1105. https://doi.org/10.1002/ldr.2318

Colazo, J.C.; Buschiazzo, D.E. 2010. Soil dry aggregate stability and wind erodible fraction in a semiarid environment of Argentina. Geoderma 159: 228-236. https://doi.org/10.1016/j. geoderma.2010.07.016

Colazo, J.C.; Buschiazzo, D.E. 2015. The impact of agriculture on soil texture due to wind erosion. Land Degradation \& Development 26: 62-70. https://doi.org/10.1002/ldr.2297

Feras, Y.; Erpul, G.; Bogman, P.; Cornelis, W.M.; Gabriels, D. 2008. Determination of efficiency of Vasaline slide and Wilson and Cook sediment traps by wind tunnel experiments. Environmental Geology 55: 741-757.

Fister, W.; Ries, J.B. 2009. Wind erosion in the central Ebro basin under changing land use management: field experiments with a portable wind tunnel. Journal of Arid Environments 73: 9961004.

Fryrear, D.W.; Krammes, C.A.; Williamson, D.L.; Zobeck, T.M. 1994. Computing the wind erodible fraction of soils. Journal of Soil and Water Conservation 49: 183-188.

Giménez, A.; Lozano, F.J.; Torres, J.A.; Asensio, C. 2019. Automated system for soil wind erosion studies. Computers and Electronics in Agriculture 164: 104889.

Goossens, D.; Buck, B.J. 2012. Can BSNE (Big Spring Number Eight) samplers be used to measure PM10, respirable dust, PM2.5 and PM1.0? Aeolian Research 5: 43-49.
Goossens, D.; Offer, Z.; London, G. 2000. Wind tunnel and field calibration of five aeolian sand traps. Geomorphology 35: 233252.

IUSS Working Group WRB. 2015. International soil classification system for naming soils and creating legends for soil maps. Food and Agriculture Organization of the United Nations, Rome. (World Soil Resources Reports, 106).

Katra, I.; Gross, A.; Swet, N.; Tanner, S.; Krasnov, H.; Angert, A. 2016. Substantial dust loss of bioavailable phosphorus from agricultural soils. Scientific Reports 6: 24736. https://doi. org/10.1038/srep24736

Marzen, M.; Iserloh, T.; Fister, W.; Seeger, M.; Rodrigo Comino, J.; Ries, J.B. 2019. On-site water and wind erosion experiments reveal relative impact on total soil erosion. Geosciences 9: 478. https://doi.org/10.3390/geosciences9110478

Mendez, M.J.; Funk, R.; Buschiazzo, D.E. 2011. Field wind erosion measurements with Big Spring Number Eight (BSNE) and Modified Wilson and Cook (MWAC) samplers. Geomorphology 129: 43-48.

Novara, A.; Gristina, L.; Saladino, S.S.; Santoro, A.; Cerdà, A. 2011. Soil erosion assessment on tillage and alternative soil managements in a Sicilian vineyard. Soil Tillage Research 117: 140-147. https://doi.org/10.1016/j.still.2011.09.007

Panagos, P.; Van Liedekerke, M.; Jones, A.; Montanarella, L. 2012. European Soil Data Centre: response to European policy support and public data requirements. Land Use Policy 29: 329-338. https://doi.org/10.1016/j.landusepol.2011.07.003

Prosdocimi, M.; Cerdà, A.; Tarolli, P. 2016. Soil water erosion on Mediterranean vineyards: a review. Catena 141: 1-21.

Weber, J.; Kocowicz, A.; Debicka, M.; Jamroz, E. 2017. Changes in soil morphology of Podzols affected by alkaline fly ash blown out from the dumping site of an electric power plant. Journal of Soils and Sediments 17: 1852-1861. https://doi.org/10.1007/ s11368-016-1599-7

Zobeck, T.M.; Sterk, G.; Funk, R.; Rajot, J.L.; Stout, J.E.; Van Pelt, R.S. 2003. Measurement and data analysis methods for fieldscale wind erosion studies and model validation. Earth Surface Processes and Landforms 28: 1163-1188.

Zobeck, T.M.; Baddock, M.; Van Pelt, R.S.; Tatarko, J.; AcostaMartínez, V. 2013. Soil property effects on wind erosion of organic soils. Aeolian Research 10: 43-51. https://doi. org/10.1016/j.aeolia.2012.10.005 